\title{
RESITS IN HIGHER EDUCATION: MERELY A BAR TO JUMP OVER, OR DO THEY GIVE A PEDAGOGICAL 'LEG UP'?
}

\author{
Steven Proud
}

Discussion Paper 14 / 645

21 July 2014

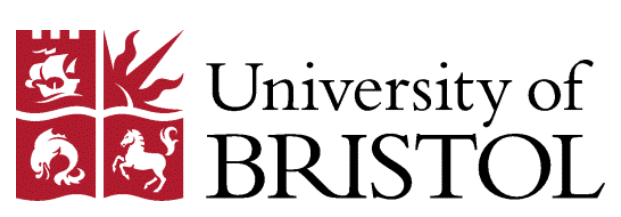

Department of Economics

University of Bristol

8 Woodland Road

Bristol BS8 1TN

United Kingdom 
Resits in Higher education: Merely a bar to jump over, or do they give a pedagogical 'leg up'?

\author{
Steven Proud ${ }^{1}$ \\ University of Bristol
}

July 2014

\begin{abstract}
When students fail an examination at the end of their first year, they are offered a free resit examination, which they merely need to pass to progress into the second year. These resits anecdotally provide a dual purpose of testing that students have achieved the required level of attainment to progress, and to incentivise additional effort from these low attaining students. This paper uses regression discontinuity design to attempt to estimate the effect of resits in first year statistics with econometrics examinations on future outcomes. Whilst resits alone appear to make zero significant effect on outcomes, students who perform well on the resit examination perform 0.7 standard deviations better in second year microeconomics than similar students who do not receive resit examinations. These effects, if replicated more widely, could be worth up to $£ 48,000$ across the lifetime of each student.
\end{abstract}

Keywords: resits; examinations; economics

\title{
Introduction
}

In the UK, university students are routinely examined in high-stakes assessments at the end of each academic year. In the vast majority of UK universities, the examinations sat in the first year of study do not count towards the final degree classification, and these examinations are merely used as a qualification year, to determine whether students are allowed to progress into the second year of the course. However, these first year examinations may be used by staff when writing references. Usually, the students

\footnotetext{
${ }^{1}$ Steven.Proud@bristol.ac.uk. 8 Woodland Road, Bristol, BS8 1TN
} 
who fail these examinations are offered resit examinations, which serve a dual purpose. Primarily, these resits are to offer the student a second chance to show that they have achieved the required academic standards to progress into the next year. Of more interest to us though, is the secondary purpose, which is to encourage the failing students to spend the summer working for these resits, which may mean that concepts, techniques and working practices are fresh in the heads of those experiencing resits over their peers who passed their examinations at first attempt. The aim of this paper is to examine whether students who experience the treatment effect of a resit examination also experience any uplift in their second year examination performance, compared with their peers who did not receive a similar resit.

The literature on resit examinations in universities is rather underdeveloped, with Ricketts $(2010,351)$ claiming that there is "no theory of resits" within the literature. The main findings of the literature are that students perform better in resit examinations than in the primary examination, and these may be put down to better preparedness, extra tuition, increased effort, and the ability to take the examination in isolation from other subjects (Pell, Boursicott and Roberts (2009)).

The school education literature does, however, offer some insight into how students may react to increased effort over the summer vacation. Jacob and Lefgren (2004) examine the introduction of a compulsory summer school for low achievers in examinations, and using a regression discontinuity design find significant positive effects for third graders, but no significant effects for sixth graders. Similar, small results of extra tuition over the summer produce positive, small effects (Zvoch and Stevens (2011), Matsudaira (2008)).

However, whilst there is a reasonably developed literature for the effect of extra tuition over the summer, there does not appear to be any developed literature for the 
medium to long-run effect of having self-motivated study for a resit examination over the summer vacation. Intuitively, it may be expected that since students who experience resits are likely to be exerting more effort, at a time when other students have little or no incentive to exert effort, then students with resits may be expected to perform better than similar peers who do not receive the treatment. However, since students are likely not to react to the treatment in a homogenous manner, it is also possible that, dependent on preferences, they may exert differential levels of effort. In this paper, I attempt to examine the effect of having a resit on future outcomes. Further, I examine whether there is any heterogeneity in future outcomes, depending on the performance within the resit examination. I take advantage of the discontinuity of treatment at a mark of 40 in the first year statistics with econometrics examination to compare otherwise similar students, one group who receives the treatment of a resit examination, and a second group who do not.

\section{Theory}

Students' examination scores can be modelled using an educational production function, similar to the general cumulative model, as suggested by Todd and Wolpin (2003). Students outcomes are a function of individual characteristics, knowledge and prior attainment,

$$
Y_{i s t}=f\left(X_{i}, K_{i s t}, A_{i t}\right)
$$

$\mathrm{Y}$ is the outcome in subject $s$ at time $t$ for individual $i$. Individual $i$ has underlying time-invariant characteristics $X$, acquired knowledge $K$ and acquired attainment $A$. Whilst knowledge is usually subject specific, aptitude is likely to have benefits across subjects, as skills learnt in one subject (such as study skills, mathematical techniques, analytical skills etc.) can benefit other subjects as well. Both 
knowledge and learnt aptitude are a function of all prior efforts, $E$, and teaching inputs, $T$. i.e. We can represent knowledge as a function of prior knowledge at time (t-1), teaching input at time $t$ and effort at time $t$.

$$
K_{i s t}=g\left(E_{i s t}, T_{\mathrm{ist}}, K_{i s(t-1)}\right), A_{i t}=h\left(E_{i s t}, T_{i s t}, A_{i(t-1)}\right)
$$

When individuals exert effort, focused on any given subject, their acquired knowledge and learnt aptitude in that subject would be expected to increase, leading to a higher performance in their examinations. However, in periods where $\mathrm{E}=0$ and $\mathrm{T}=0$, it is likely that both K and A will diminish. Cooper et al (1996) suggest that the during the summer vacation, students lose approximately $1 / 10^{\text {th }}$ of a standard deviation in attainment tests, with a particularly marked effect in mathematics.

It is assumed that students, when they are choosing their effort level at any given time, are trying to maximize their utility, which is a function of their discounted present value of future earnings, which in turn is a function of their outcome $\mathrm{Y}$, and also contemporaneous, short term utility. Since the resit examinations we consider in this paper are at the end of the students' first year at university, they are at least two years away from the job market, and as suggested in Metcalfe, Burgess and Proud (2011), students have a relatively high discount rate, many students may only consider their contemporaneous, short term, utility when making their decisions about effort levels.

During the summer vacation, $\mathrm{T}$ is necessarily 0 for all students. Students will also have the choice between exerting effort on their studies, or some outside option, such as paid work, or consumption of leisure. However, the short term return for effort on studies will be different for a sub-group of students, as students who have failed their examinations in June will have a resit examination in September, which they must pass in order to progress into the subsequent year. As such, we would expect students who 
have a resit examination to exert more effort on their studies during the summer vacation than students who have passed all their examinations in June. It should be noted that the productivity of effort during the vacation (when no teaching is received) may also be impacted by the quality of teaching received in the previous period, but this does not affect the overall thesis of this paper.

In order to ensure progression to the subsequent year, the only requirement is that students gain a mark greater than $40 \%$ in the resit examination. As such, in terms of short term utility maximisation, since effort is costly, the optimal strategy would be to choose an effort level which corresponds to gaining a mark of 40 in this resit examination. However, whilst effort is correlated to the mark gained in the resit examination, students may not know, precisely, how effort translates into examination mark, and similarly, there may be a non-trivial random error term. As such, individuals' beliefs will affect the level of effort that they exert in preparation for their resit examinations in order to ensure safe passage to the next academic year. Students who believe that a low level of effort is required to pass the examination will likely exert a low level of effort, whilst students who believe a high level of effort, will likely exert a high level of effort. Furthermore, the level of effort exerted is likely to be correlated with the level of risk-aversion of the individual, with more risk-averse individuals likely to put a higher level of effort, whilst risk-loving individuals may be willing to put in a much lower level of effort, leading to the possibility of failing, but with an increase in short-term utility, at the potential cost of long-term utility.

Students without resit examinations have a much lower incentive to put in effort over the vacation. Whilst a student with a mark close to the fail-mark of 40 may be encouraged to study over the summer, there will be less incentive for this student to actively put in effort, since this will involve a cost to their short term utility, and unless 
they have a very low discounting rate, the effort exerted over the summer will have a miniscule effect on their long-term utility.

As such, we have two, distinct groups: Firstly the group of students who receive the treatment of a resit examination in September, and secondly, the control group who do not receive the treatment. Within the treatment group, we would expect there to be differential levels of effort, but we would expect students who put in high effort in the treatment group to unambiguously exert more effort than students in the control group. Based on the theory, we would expect students who have received the treatment to begin the next academic year with a higher level of aptitude and knowledge than similar peers who have not received the treatment.

\section{Structure of Data}

The university year in England runs from the end of September through to the end of June the following year. Students are largely taught between late September and midDecember, and then from early January to late March. In the data we use here, all of the assessments are via examinations in May and June, although the structure of assessments differs across universities and programmes. During the teaching period, students are usually required to submit assignments for formative assessments. Second year courses generally build on concepts, and use methodologies taught in first year units. Whilst usually the first year courses are essentially pass/fail examinations, allowing progression to the next academic year, there are still incentives for students to put in high effort, as these marks can be used to inform references for internships.

Outcomes in the second year examinations are important for students, as these usually contribute significantly towards a student's final degree classification.

The data is taken from 6 years of second year results in core economics units at a Russell Group university, which means that it is a research intensive university. In the 
first year of academic studies, students within the School of Economics, Finance and Management at this university are all examined in microeconomics, macroeconomics, mathematics, and statistics with econometrics, and then are also examined in two additional subjects, which may be offered by different departments within the school (such as Accounting and Finance, or Management), or alternatively in open units from outside of the School. In the second year, all students who have economics as a core part of their degree study microeconomics and macroeconomics, whilst most students study econometrics. In order to have consistency in estimation, whilst keeping sample sizes large enough, I consider only students who are registered for degrees with compulsory micro- and macro-economics in the second year.

In any given examination, the pass mark is 40 . Students gaining a mark lower than 40 are deemed to have failed the unit, and students are required to make up the credits for that unit. Students who fail examinations in the first year are automatically given a resit paper in the same subject, which is examined in the September prior to starting their second year. The data is taken from students who sat their second year examinations between 2006 and 2012, and their first year examinations between 2005 and 2011. Within a cohort, all students receive approximately the same teaching inputs, with core material delivered through lectures, and reinforcement of the material through exercise lectures (large group classes where a lecturer goes through problems students have prepared in advance of the class), assignments and often small group tutorials (containing approximately 15 students). Microeconomics and macroeconomics had a slightly different structure for students examined from $2007-2009$, as in these subjects there were a higher number of exercise lectures, but no small group tutorials. Small group tutorials were reintroduced for microeconomics and macroeconomics for students examined in 2010. However, despite the change in teaching method, we would not 
expect this to impact largely on our results. This is because teaching within cohort is constant, and dummy variables are included to control for year of examination, which should control for the change in teaching methods. However, in order to examine this possibility, as robustness checks, I will examine students examined sitting their examinations in 2010-2012 separately from the rest of the data

Table 1 gives summary statistics for results in the dataset. In first year examinations, as might be expected for quantitative examinations, mathematics and, statistics with econometrics both have a very high variance in their scores. On average, students struggle with econometrics in the first year, with a low mean score. This is unsurprising, as whilst the techniques and knowledge in mathematics, microeconomics and macroeconomics will be familiar to most students, econometrics is often new to all students, and conceptual issues with relation to econometrics often tend to be areas students struggle with, particularly in the first year. For second year examinations, microeconomics has a similar variance to the mathematics, and statistics with econometrics units in the first year, along with a low average mark. Again, this is unsurprising, as second year econometrics focusses on game theoretical concepts, and is largely a quantitative examination, which students often struggle with. However, in order to provide comparability across years and subjects, prior to the omission of students, the examination results are standardised, by examination year and subject, to mean 0 , standard deviation 1 .

\section{Identification Strategies}

In this paper, we try to assess the effect of resit examinations in the September prior to beginning to the second year on performance in examinations in the subsequent June. At the end of each academic year, students are examined in the subjects they have been studying in that academic year. In the examinations at the end of the first and second 
years, if a student gains a mark lower than 40 , they are deemed to have failed the examination, and are offered a resit in that subject the following September. As discussed above, students with resits (particularly those who gain a high mark in the resit) are likely to have exerted high effort over the summer vacation. However, it is not possible to say anything about the level of effort between September and the following June. As such, any observed effect will be the effect of the increased effort level between June and September, plus any effect of changes in behaviour between September and June compared with students who did not receive the treatment.

As such, we are interested in the following specification:

$$
Y_{i s t}=\beta_{0}+\beta_{1} \text { resit }_{i(t-1)}+\beta_{2} X_{i s(t-1)}+u_{t}
$$

where $Y$ is the outcome for individual $i$ in subject $s$ at time $t$ (at the end of the second year), resit is a dummy variable that takes the value 1 if student $i$ has one resit examination at the end of the first year. $X$ is a vector of individual level characteristics and prior inputs, modelled using attainment at the end of the first year. In order to estimate this, I use Ordinary Least Squares (OLS), which fits a relationship by minimising the sum of squares of the residuals $\left(u_{t}\right)$.

However, even with controls for prior attainment, since students who receive the treatment are likely to be lower ability students, a naïve ordinary least squares (OLS) specification including all students will likely lead to estimates of the effect of a resit (and a good performance in a resit) being biased. In order to gain a credibly exogenous treatment group with a similar control group, a common strategy in the education economics literature is to take advantage of a regression discontinuity design method (Feng and Graetz (2013), Jacob and Lefgren (2004)) But, students who gain a pass in the June examination with a mark close to 40 are likely not to be quantitatively different 
from students who fail the examination in June, but gain a mark close to 40 . Lee and Lemieux (2010) suggest that provided individuals cannot perfectly predict whether the level of effort they exert will lead to passing (or failing) the exam, then an obvious identification strategy would be to take advantage of a regression discontinuity design, as around the discontinuity, assignment is essentially random. This assumption is feasible in this case for several reasons. Firstly, the students have not had prior experience of examinations at a university level, and so are unlikely to know the precise level of effort required to gain a marginal pass mark. Secondly, the educational literature acknowledges that even when students can predict accurately the returns to effort, there will still be random shock terms which affect the realised grade. (e.g. Kane and Staiger (2002)). Hence, we use a regression discontinuity design specification, centred around the pass mark of 40 to identify the effect of having a resit at the end of the first year on outcomes at the end of the second year.

Since all students are offered the same level of tuition, any effect that is observed should give us estimates of the effectiveness of a change in effort level on outcomes, triggered by having to work hard for a resit examination. However, the effort level given in response to a resit examination is likely to be heterogeneous across student types, dependent on preferences. As a simplified model, we can consider the mark in the resit (resit_mark) as a proxy for the effort level that the student exerts. Whilst this will not give a perfect correlation between high effort and later outcomes, it will give an indicative result. As such, we are interested in estimating the following specification:

$$
Y_{i s t}=\beta_{0}+\beta_{1} \text { resit }_{i(t-1)}+\beta_{2} \text { resit_mark }_{i(t-1)}+\beta_{3} X_{i s(t-1)}+u_{t}
$$


This identification strategy is only practical for students who have failed one examination, as if they have failed multiple examinations, again, this is usually a signal of low ability, which would lead to an underestimation of the effect of a resit on outcomes. Furthermore, this identification strategy will only allow us to compare, say, a treatment group of students who have failed their statistics with econometrics unit (and no other examinations), with the control group of students who have passed all of their core economics units and have no resit examinations. As such, any student who fails more than one examination is dropped from the sample. Furthermore, any student who fails any examinations outside of the core economics modules is also dropped from the sample. It is possible that some students have failed a unit offered outside of the school of EFM, for which we don't have data. Since the skills gained in these subjects are much less likely to be transferrable to economics, resits in these subjects are less likely to have a quantitative effect on outcomes. Furthermore, students have a higher propensity to fail their core units within the School of EFM than their optional units; students who fail an optional unit almost always also fail (at least) one of their core units.

Since all students in the school of EFM are examined in 4, core, units, we have four possible treatment groups:

- Students who fail microeconomics, but no other core examinations

- Students who fail macroeconomics, but no other core examinations

- Students who fail mathematics, but no other core examinations

- Students who fail statistics with econometrics, but no other core examinations.

However, Table 2 shows the number of other examinations students fail, conditional on failing microeconomics, macroeconomics, mathematics or statistics with 
econometrics. There are 44 possible students who receive treatment in group 4 , but for groups 1,2, and 3, the possible treatment groups are 5, 5 and 11, respectively. Due to the lack of data here, we ignore these possible treatment groups, and concentrate on group 4; students who fail statistics with econometrics, but fail no other examinations.

One concern with this methodology is that there may be further selection issues; we only observe students in second year examinations if they have gained a mark of (at least) 40 in the resit examination. However, in the data we observe here, there are only two students who experience a single resit in statistics with econometrics, which they fail, denying them entry to the second year of study. As such, it is not viable to estimate a selection model, but by including the mark gained in the resit examination, we should mitigate against any sort of censoring bias here.

\section{Results}

In order to assess the effect of having a resit on outcomes, an obvious place to start would be naïve OLS estimates of equation (3):

$$
Y_{i s t}=\beta_{0}+\beta_{1} \text { resit }_{i(t-1)}+\beta_{2} X_{i s(t-1)}+u_{t}
$$

Table 3 shows estimates of equation (3) using a naïve OLS specification using all observations within the data, using prior attainment in micro, macro and mathematics as controls, as well as the square of the student's prior attainment in first year statistics with econometrics. (This allows for a non-linear relationship to be estimated). The results, whilst positive for microeconomics and econometrics, are not statistically significant.

For macroeconomics, there is a very small negative effect estimated, which is again, not statistically significant. However, as discussed earlier, it is likely that these results are biased; since we have included the entire data-set, it is reasonable to assume 
that the treatment group (who receive resit examinations) will be quantifiably different from the non-treatment group. For example, we would expect students who fail their first year statistics with econometrics examination at first attempt to be, on average, lower attainers than students who passed. As such, a more believable strategy would be to use a regression discontinuity design approach.

\section{Choice of window}

In order to use a regression discontinuity design (RDD) specification, we need to choose an appropriate window which includes a sample of students who are just above the pass mark, and a sample of students who are just below the pass mark. For an RDD specification, there is a trade-off between potential bias if the window is too large, and a lack of efficiency if the chosen window is too small. As such, in this paper, we attempt to calibrate my window by examining the effect of initially starting with observations close to the cut off, and expand to increase the coverage. Table 4 shows the 6 RDD specifications considered in this paper, as well as the number of observations remaining, and number of students who are treated and untreated in each window.

These windows are all centred on a mark of 39 in the first year examination, since marking guidelines are to avoid 39s. As such, specification I, for example, contains 3 marks for which students receive a resit, and 3 marks for which students do not receive a resit. Specifications I, II and II have relatively low sample sizes, and may give inefficient results, but we may have more confidence about the efficiency in specifications IV, V and VI.

\section{RDD results}

Table 5 offers estimates of the effect of resits on outcomes for students on their second year examinations in microeconomics, macroeconomics and econometrics. Again, the 
results are largely positive for microeconomics and macroeconomics, but these effects are largely, statistically insignificant, with the notable exception for the most restrictive specification in microeconomics. However, due to sample sizes, it is likely that this is a random anomaly, rather than a suggestion of a causal effect of resits. However, even having said this, the effects are largely positive for both microeconomics and macroeconomics, with the effect of a resit estimated at between 0.1 and 0.4 standard deviations increase in test score over those without a resit. There is, however, a lack of precision from these estimates, which makes conclusions difficult to make, and we cannot reject the null of no effect on outcomes. For econometrics, again, we are unable to reject the null hypothesis of resits having no effect on outcomes. Compared with the results from microeconomics and macroeconomics, the point estimates are much smaller, and are not consistently positive.

\section{Differential levels of effort}

As discussed above, it is likely that students effort levels in response to a resit (and the effect this may have on their future effort levels) will be heterogeneous. In order to model the change in effort level, we estimate equation (4), again beginning with naïve OLS estimates

$$
Y_{i s t}=\beta_{0}+\beta_{1} \text { resit }_{i(t-1)}+\beta_{2} \text { resit_mark }_{i(t-1)}+\beta_{3} X_{i s(t-1)}+u_{t}
$$

The interpretation of the results here is a little more complicated; in order to estimate the effect of a resit on an individual's results, we need to consider both the impact of having a resit $\left(\beta_{1}\right)$, but also the effect of the mark that they gained in a resit

$\beta_{2}$. As such, we cannot interpret these two coefficients in isolation, as all students who have a resit also gain a mark in the resit examination. In order to interpret the effect of a resit with "high effort" compared with a resit with "low effort" leads us to compare 
the effect of a resit for a student who gains a mark of 40 (a marginal pass) in the resit examination with a student who gains a mark of 70 (a very high pass) in the resit examination, and comparing both groups with the group who do not receive a resit.

The estimated effect of a resit, dependent on mark, is shown in Table 6, which illustrates naïve OLS estimates of the effect of a resit on outcomes, using the entire data sample. In these simple specifications, the estimated coefficient for students gaining a mark of 40 is consistently negative, for all subjects, but is only marginally statistically significant for macroeconomics, whilst the effect of gaining a mark of 70 in the resit examination is consistently positive. In microeconomics, the point estimates of a mark of 70 in a resit examination is to raise the grade in second year examinations by 0.414 standard deviations over students who experience no resit exam, whilst for econometrics a statistically significant effect of 0.574 standard deviations is observed. In macroeconomics, the effect of a mark of 70 is smaller, and is insignificant. It is still likely that these estimates are biased, and a more credible identification strategy is to, again, use the RDD approach, as detailed above.

Table 7 gives estimates of $\beta_{1}, \beta_{2}$, and the overall imputed effect of a "good" performance (mark equal to 70) and of a "poor" performance (mark equal to 40) in a resit examination, compared with the control group of students with no resits. For all specifications, the estimated effect of a poor performance in the resit examination is not statistically significant, although it is negative in most of the specifications. Due to small sample sizes, the estimates from specifications I, II and III are very inefficient, so we concentrate on the results from specifications IV, V and VI. For both microeconomics and macroeconomics, the marginal effect of an additional mark in the 
resit examination has an effect of improving outcomes by approximately 0.03 standard deviations, and this is statistically significantly different from zero in specificiations $\mathrm{V}$ and VI. This suggests that a student who gains a mark of 55 in the resit, compared with a student who gains a mark of 45 would be expected to perform 0.3 standard deviations higher in the second year microeconomics and macroeconomics examinations. Comparing the effect of a "good" resit mark with not experiencing a resit at all, the results suggest that a student who experiences a resit, and gains a mark of 70 in that resit is likely to perform between 0.6 and 0.7 standard deviations better in their second year microeconomics exam. Similar point estimates are also seen of a good performance in a resit on macroeconomics results, albeit insignificant effects, whilst the estimated effects for econometrics are smaller and again insignificantly different from zero.

Students who were examined in second year microeconomics and macroeconomics from 2010 onwards experienced a marginally different teaching regime compared with those examined before. For 2010 onwards, the students had small group tutorials. One worry is that this different teaching regime over the course of the study period may affect our results. As such Table 8 offers RDD results for the period 2010-2012 for these two subjects. These results are not significantly different from those of Table 7, suggesting that the change in teaching regimes has not significantly affected the results. The major difference between these specifications is the efficiency of the estimates, but the overall point estimates of a good performance in the resit examination are largely unchanged.

\section{Validity of RDD results}

A worry with this sort of RDD specification is that the treatment group (the group experiencing resits in this case) have different characteristics from those who do not 
receive the treatment, and as such would be expected to have different levels of performance in their second year examinations. Using the estimated coefficients from Table 7, it is possible to construct fitted values for students expected performance, based on their other observed characteristics (so in this case, their performance in their mathematics, microeconomics and macroeconomics examinations, along with year dummies). Since the performance in the statistics/econometrics examination determines whether they have a resit, this must be omitted from the fitted value.

$$
\hat{Y}_{i s t}=\hat{\beta}_{0}+\hat{\beta}_{3} X_{i s(t-1)}
$$

If the two groups are quantitatively equivalent, we would expect that $\overline{\widehat{Y}}_{\text {resit }}=$ $\overline{\hat{Y}}_{\text {no resit. }}$ That is, if the two groups are equivalent, other than that one group receives a resit, whilst the others do not, then their predicted outcomes, based on all their other characteristics should be equivalent. Since the performance in the statistics with econometrics examination determines whether a student experiences a resit examination, then this needs to be omitted as well. This can be tested using a simple OLS regression of

$$
\widehat{Y}_{i s t}=\alpha_{0}+\alpha_{1} \text { resit }_{i(t-1)}+e_{i s t}
$$

The results of the tests for equivalence of mean are shown in Table 9. None of the estimated coefficients here are statistically significant, indicating that the groups are not significantly different in terms of observed characteristics. As such, the RDD methodology appears appropriate. 


\section{Discussion}

In this paper, we have tried to identify the effect of resits on future outcomes within university education. Resits serve the dual purpose of trying to ensure that students have reached the appropriate attainment threshold to pass into the next year of study, but also to try and incentivise low attaining students to put in additional work, with the aim of 'hitting the ground running' for the next academic year. The results presented here suggest that resits, on their own, may not achieve this second aim, as the overall results of students experiencing the treatment of a resit examination are not significantly different than those who do not experience the treatment, across the compulsory economics disciplines.

However, since it is likely that different students react to the incentive of a resit examination in different ways, we use the mark gained in the resit as a proxy for the level of effort they have exerted in preparing for this resit. It should be acknowledged that this is not a perfect proxy, but the results should be indicative. The results discussed here suggest that resits alone do not have any significant effect on students' outcomes; future outcomes. This raises the question of whether it is efficient to require students to experience a further examination, which would need to be marked, and the cost of man hours related to this; why not merely allow the student to demonstrate that they have achieved the level of attainment required through a less labour intensive method?

However, this is not the whole story. In microeconomics particularly, students who performed well in the resit examination for statistics with econometrics outperform both their peers who performed badly in the resit examination, and also their peers who did not experience a resit at all. The topics examined in second microeconomics do not 
build particularly on concepts learned in first year statistics with econometrics, although knowledge of probability benefits students when calculating expected utility, for example. As such, the results suggest that the mechanism is not an improvement in knowledge amongst the students who perform well in the resit examination, but rather a change to the way that they work following the resit examination.

One important question is why the effect is only significant in microeconomics, but not in macroeconomics or econometrics. For macroeconomics, the estimated effects are quantitatively similar to those for microeconomics, but the standard errors are larger. It may be, with more years of data, that the effects could be realised as significant.

The estimated effects in microeconomics are undoubtedly large. A 0.7 s.d. increase in second year microeconomics mark is equivalent to a 12.3 mark increase in their grade. Were this effect repeated more widely, then this would be equivalent to an increase of an entire grade classification. E.g. this could provide the difference between a lower and an upper second class degree. Conlon and Patrignani (2011) approximate the value of this increase as a lifetime premium of $£ 48,000$ for men, and $£ 18,000$ for women.

These results suggest that students who marginally pass an examination may actually be benefitted from experiencing a resit examination, but only if the student could be incentivised to work appropriately towards that resit examination; a resit alone would not necessarily lead to any improvement in outcomes. Similarly, if we want to improve the performance of students who marginally fail examinations, we need to ensure that the incentives are there for students to put in an appropriate level of work for their resit examination. One policy that could be considered would be to require a achieve a higher threshold in a resit examination to allow them to progress into the 
second year. However, this would disadvantage those students who marginally passed, so under this suggested policy, these students could be offered the opportunity for a similar resit opportunity.

The data considered here only allow us to compare students who gain one resit with those who marginally pass their examinations. However, there are often long tails of students who do not just fail one exam, but fail multiple examinations. Further study would be required to examine the efficacy of resit examinations for these students, and what policies could be introduced to help these students achieve to their potential. 


\section{References}

Conlon, G., and Patrignani, P. (2011). "The Returns to Higher Education Qualifications", Department for Business, Innovation and Skills. City: London.

Cooper, H., Nye, B., Charlton, K., Lindsay, J., and Greathouse, S. (1996). "The effects of summer vacation on achievement test scores: A narrative and meta-analytic review." Review of Educational Research, 66(3), 227-268.

Feng, A., and Graetz, G. (2013). "A Question of Degree: The Effects of Degree Class on Labor Market Outcomes" CEP Discussion Paper No. 1221. London School of Economics, London.

Jacob, B. A., and Lefgren, L. (2004). "Remedial education and student achievement: A regression-discontinuity analysis." Review of Economics and Statistics, 86(1), 226-244.

Kane, T. J., and Staiger, D. O. (2002). "The promise and pitfalls of using imprecise school accountability measures." Journal of Economic Perspectives, 16(4), 91114.

Lee, D. S., and Lemieux, T. (2010). "Regression Discontinuity Designs in Economics." Journal of Economic Literature, 48(2), 281-355.

Matsudaira, J. D. (2008). "Mandatory summer school and student achievement." Journal of Econometrics, 142(2), 829-850.

Metcalfe, R., Burgess, S., and Proud, S. (2011). "Student effort and educational attainment: Using the England football team to identify the education production function" CMPO Working Paper No 11/276. Centre for Market and Public Organisation, Bristol

Pell, G., Boursicot, K., and Roberts, T. (2009). "The trouble with resits ..." Assessment \& Evaluation in Higher Education, 34(2), 243-251.

Ricketts, C. (2010). "A new look at resits: are they simply a second chance?" Assessment \& Evaluation in Higher Education, 35(4), 351-356.

Todd, P. E., and Wolpin, K. I. (2003). "On the specification and estimation of the production function for cognitive achievement." Economic Journal, 113(485), F3-F33.

Zvoch, K., and Stevens, J. J. (2011). "Summer School and Summer Learning: An Examination of the Short- and Longer Term Changes in Student Literacy." Early Education and Development, 22(4), 649-675. 


\section{Tables}

Table 1. Summary Statistics

\begin{tabular}{l|cccc|ccc}
\hline & \multicolumn{4}{|c|}{ First Year } & \multicolumn{3}{c}{ Second year } \\
& $\begin{array}{c}\text { Micro- } \\
\text { economics }\end{array}$ & $\begin{array}{c}\text { Macro- } \\
\text { economics }\end{array}$ & Mathematics & $\begin{array}{c}\text { conics } \\
\text { Econometrics }\end{array}$ & $\begin{array}{c}\text { Micro- } \\
\text { economics }\end{array}$ & $\begin{array}{c}\text { Macro- } \\
\text { economics }\end{array}$ & Econometrics \\
\hline Mean & 58.70 & 57.83 & 66.64 & 54.80 & 51.90 & 55.66 & 53.52 \\
SD & 11.25 & 10.92 & 17.59 & 17.59 & 17.58 & 12.94 & 16.21 \\
$\mathrm{n}$ & 1239 & 1194 & 1223 & 1230 & 1496 & 1265 & 827 \\
\hline
\end{tabular}

Notes: The data included here is raw data for all students examined in first year examinations from 2006-2011, and from second year examinations between 2007 -2012. This includes all students within the School. 
Table 2. Number of examinations failed by students, having failed at least one.

\begin{tabular}{c|c|c|c|c}
\hline $\begin{array}{c}\text { Number of } \\
\text { other } \\
\text { examinations } \\
\text { failed }\end{array}$ & Microeconomics & Macroeconomics & Mathematics & $\begin{array}{c}\text { Statistics with } \\
\text { econometrics }\end{array}$ \\
\hline 0 & 5 & 5 & 11 & 44 \\
1 & 7 & 3 & 12 & 23 \\
2 & 5 & 6 & 9 & 17 \\
3 & 2 & 1 & 2 & 4 \\
\hline
\end{tabular}

Notes: The numbers represent the number of students who fail 0, 1, 2 or 3 other examinations, having failed micro, macro, mathematics or statistics with econometrics 
Table 3. Naïve OLS estimates of the effect of resits on outcomes

\begin{tabular}{lccc}
\hline & Microeconomics & Macroeconomics & Econometrics \\
\hline Resit & $\mathbf{0 . 2 0 7}$ & $\mathbf{- 0 . 0 1 4}$ & $\mathbf{0 . 2 4 6}$ \\
& $(0.203)$ & $(0.206)$ & $(0.232)$ \\
Statistics with & $0.277^{* * *}$ & $0.241^{* * *}$ & $0.355^{* * *}$ \\
econometrics (X) & $(0.088)$ & $(0.088)$ & $(0.093)$ \\
Mathematics & 0.097 & $0.125^{* *}$ & 0.095 \\
& $(0.064)$ & $(0.059)$ & $(0.070)$ \\
Microeconomics & $0.380^{* * *}$ & $0.268^{* * *}$ & $0.168^{* * *}$ \\
& $(0.057)$ & $(0.048)$ & $(0.065)$ \\
Macroeconomics & $0.152^{* * *}$ & $0.183^{* * *}$ & $0.236^{* * *}$ \\
& $(0.057)$ & $(0.050)$ & $(0.061)$ \\
$\mathrm{X}^{2}$ & 0.017 & 0.021 & -0.072 \\
& $(0.062)$ & $(0.061)$ & $(0.050)$ \\
\hline$R^{2}$ & 0.27 & 0.31 & 0.27 \\
$N$ & 569 & 569 & 420 \\
\hline
\end{tabular}

Note: Dependent variable is the outcome at the end of the second year in micro- macro-economics or econometrics. Dependent variables are standardised to mean zero, standard deviation one, by examination year. Prior attainments are similarly standardised. Dummies are included for year that student sat their second year examinations. Resit indicates that the student had a resit examination in first year statistics with econometrics, but in no other subject. $* * *$ indicates significant at $1 \%$ significance level, $* *$ indicates significant at $5 \%$ significance level, $*$ indicates significant at $10 \%$ significance level. Robust standard errors in parentheses 
Table 4. Descriptions of RDD windows and the number of students treated and untreated in each sample

\begin{tabular}{l|c|c|c|c|c|c|c}
\hline Specification & $\begin{array}{c}\text { Full } \\
\text { Sample } \\
\text { N/A }\end{array}$ & $36-42$ & $35-43$ & $34-44$ & $33-45$ & $32-46$ & $31-47$ \\
Mark range & 569 & 37 & 45 & 57 & 71 & 86 & 105 \\
\hline Microeconomics & & 11 & 13 & 15 & 20 & 24 & 27 \\
Observations & 44 & & & & & & II \\
\hline Macred & 569 & 37 & 45 & 57 & 71 & 86 & 105 \\
Observations & 44 & 11 & 13 & 15 & 20 & 24 & 27 \\
Treated & 420 & 24 & 27 & 35 & 44 & 53 & 66 \\
\hline Econometrics & 28 & 9 & 10 & 11 & 16 & 18 & 19 \\
\hline $\begin{array}{l}\text { Observations } \\
\text { Treated }\end{array}$ & & & & & & & \\
\hline
\end{tabular}


Table 5. Regression discontinuity estimates of the effect of resits on later outcomes.

\begin{tabular}{|c|c|c|c|c|c|c|}
\hline & I & II & III & IV & $\mathrm{V}$ & VI \\
\hline \multicolumn{7}{|l|}{$\underline{\text { Microeconomics }}$} \\
\hline $\begin{array}{l}\text { Resit in first year statistics } \\
\text { with econometrics }\end{array}$ & $\begin{array}{c}\mathbf{0 . 8 6 7} \\
(0.620)\end{array}$ & $\begin{array}{c}\mathbf{0 . 3 0 5} \\
(0.555)\end{array}$ & $\begin{array}{c}\mathbf{0 . 1 6 1} \\
(0.510)\end{array}$ & $\begin{array}{c}\mathbf{0 . 4 6 3} \\
(0.399)\end{array}$ & $\begin{array}{c}\mathbf{0 . 4 3 0} \\
(0.352)\end{array}$ & $\begin{array}{c}\mathbf{0 . 4 5 5} \\
(0.324)\end{array}$ \\
\hline$R^{2}$ & 0.36 & 0.35 & 0.26 & 0.32 & 0.29 & 0.27 \\
\hline$N$ & 37 & 45 & 57 & 71 & 86 & 105 \\
\hline \multicolumn{7}{|l|}{ Macroeconomics } \\
\hline $\begin{array}{l}\text { Resit in first year statistics } \\
\text { with econometrics }\end{array}$ & $\begin{array}{c}\mathbf{0 . 4 3 5} \\
(0.716)\end{array}$ & $\begin{array}{l}\mathbf{- 0 . 1 4 7} \\
(0.562)\end{array}$ & $\begin{array}{c}\mathbf{0 . 1 2 4} \\
(0.491)\end{array}$ & $\begin{array}{c}\mathbf{0 . 3 0 5} \\
(0.411)\end{array}$ & $\begin{array}{c}\mathbf{0 . 2 8 3} \\
(0.365)\end{array}$ & $\begin{array}{c}\mathbf{0 . 2 1 0} \\
(0.323)\end{array}$ \\
\hline$R^{2}$ & 0.34 & 0.28 & 0.26 & 0.26 & 0.22 & 0.25 \\
\hline$N$ & 37 & 45 & 57 & 71 & 86 & 105 \\
\hline \multicolumn{7}{|l|}{ Econometrics } \\
\hline $\begin{array}{l}\text { Resit in first year statistics } \\
\text { with econometrics }\end{array}$ & $\begin{array}{c}\mathbf{0 . 0 8 7} \\
(0.731)\end{array}$ & $\begin{array}{l}\mathbf{- 0 . 1 9 6} \\
(0.656)\end{array}$ & $\begin{array}{c}\mathbf{0 . 0 4 2} \\
(0.495)\end{array}$ & $\begin{array}{c}\mathbf{0 . 2 1 5} \\
(0.434)\end{array}$ & $\begin{array}{l}\mathbf{- 0 . 0 4 7} \\
(0.378)\end{array}$ & $\begin{array}{c}\mathbf{0 . 1 3 4} \\
(0.373)\end{array}$ \\
\hline$R^{2}$ & 0.61 & 0.47 & 0.68 & 0.43 & 0.33 & 0.29 \\
\hline$N$ & 24 & 27 & 35 & 44 & 53 & 66 \\
\hline
\end{tabular}

Note: Dependent variable is the outcome at the end of the second year in micro- macro-economics or econometrics. Dependent variables are standardised to mean zero, standard deviation one, by examination year. Prior attainments are similarly standardised. Dummies are included for year that student sat their second year examinations. Resit indicates that the student had a resit examination in first year statistics with econometrics, but in no other subject. *** indicates significant at $1 \%$ significance level, ** indicates significant at $5 \%$ significance level, * indicates significant at $10 \%$ significance level. Robust standard errors in parentheses 
Table 6. Naïve OLS estimates of the effect of resits on outcomes with controls for performance in resit examination

\begin{tabular}{|c|c|c|c|}
\hline & Microeconomics & Macroeconomics & Econometrics \\
\hline Resit & $\begin{array}{c}\mathbf{- 0 . 8 3 0} \\
(0.717)\end{array}$ & $\begin{array}{c}\mathbf{- 1 . 6 2 2} * * \\
(0.739)\end{array}$ & $\begin{array}{c}\mathbf{- 1 . 4 7 9} * \\
(0.887)\end{array}$ \\
\hline Resit mark & $\begin{array}{c}\mathbf{0 . 0 1 8} \\
(0.012)\end{array}$ & $\begin{array}{c}\mathbf{0 . 0 2 8} * * \\
(0.012)\end{array}$ & $\begin{array}{c}\mathbf{0 . 0 2 9} * * \\
(0.014)\end{array}$ \\
\hline Statistics with econometrics (X) & $\begin{array}{c}0.260 * * * \\
(0.088)\end{array}$ & $\begin{array}{c}0.215^{* * *} * \\
(0.083)\end{array}$ & $\begin{array}{c}0.331 * * * \\
(0.096)\end{array}$ \\
\hline Mathematics & $\begin{array}{c}0.094 \\
(0.064)\end{array}$ & $\begin{array}{c}0.119 * * \\
(0.057)\end{array}$ & $\begin{array}{c}0.081 \\
(0.069)\end{array}$ \\
\hline Microeconomics & $\begin{array}{c}0.376 * * * \\
(0.057)\end{array}$ & $\begin{array}{c}0.263 * * * \\
(0.048)\end{array}$ & $\begin{array}{c}0.167 * * \\
(0.065)\end{array}$ \\
\hline Macroeconomics & $\begin{array}{c}0.152 * * * \\
(0.057)\end{array}$ & $\begin{array}{c}0.183 * * * \\
(0.050)\end{array}$ & $\begin{array}{c}0.229 * * * \\
(0.061)\end{array}$ \\
\hline$X^{2}$ & $\begin{array}{c}0.033 \\
(0.063) \\
\end{array}$ & $\begin{array}{c}0.045 \\
(0.056)\end{array}$ & $\begin{array}{l}-0.048 \\
(0.055)\end{array}$ \\
\hline $\begin{array}{l}R^{2} \\
N\end{array}$ & $\begin{array}{l}0.28 \\
569\end{array}$ & $\begin{array}{l}0.32 \\
569\end{array}$ & $\begin{array}{l}0.28 \\
420\end{array}$ \\
\hline $\begin{array}{l}\text { Overall effect of a mark of } \mathbf{4 0} \text { in } \\
\text { resit } \\
\text { Overall effect of a mark of } \mathbf{7 0} \text { in } \\
\text { resit }\end{array}$ & $\begin{array}{l}\mathbf{- 0 . 1 1 9} \\
(0.301) \\
\mathbf{0 . 4 1 4 *} \\
(0.230) \\
\end{array}$ & $\begin{array}{c}\mathbf{- 0 . 5 1 9 *} \\
(0.295) \\
\mathbf{0 . 3 0 9} \\
(0.247) \\
\end{array}$ & $\begin{array}{l}\mathbf{- 0 . 3 0 6} \\
(0.379) \\
\mathbf{0 . 5 7 4 * *} \\
(0.228) \\
\end{array}$ \\
\hline
\end{tabular}

Note: Dependent variable is the outcome at the end of the second year in micro- macro-economics or econometrics. Dependent variables are standardised to mean zero, standard deviation one, by examination year. Prior attainments are similarly standardised. Dummies are included for year that student sat their second year examinations. Resit indicates that the student had a resit examination in first year statistics with econometrics, but in no other subject. The resit mark is the mark gained in the resit examination; the pass mark is 40 . *** indicates significant at $1 \%$ significance level, $* *$ indicates significant at $5 \%$ significance level, * indicates significant at $10 \%$ significance level. Robust standard errors in parentheses 
Table 7. Regression discontinuity estimates including a control for performance in resit examinations

\begin{tabular}{|c|c|c|c|c|c|c|}
\hline & I & II & III & IV & $\mathrm{V}$ & VI \\
\hline \multicolumn{7}{|l|}{$\underline{\text { Microeconomics }}$} \\
\hline Resit & $\begin{array}{c}\mathbf{1 . 0 8 4} \\
(1.989)\end{array}$ & $\begin{array}{c}\mathbf{- 0 . 1 1 4} \\
(1.933)\end{array}$ & $\begin{array}{c}\mathbf{- 2 . 1 9 7} \\
(1.692)\end{array}$ & $\begin{array}{c}\mathbf{- 1 . 2 5 8} \\
(1.380)\end{array}$ & $\begin{array}{c}\mathbf{- 1 . 4 0 0} \\
(1.041)\end{array}$ & $\begin{array}{l}\mathbf{- 1 . 1 9 5} \\
(0.977)\end{array}$ \\
\hline Resit mark & $\begin{array}{c}\mathbf{- 0 . 0 0 4} \\
(0.028)\end{array}$ & $\begin{array}{c}\mathbf{0 . 0 0 7} \\
(0.026)\end{array}$ & $\begin{array}{c}\mathbf{0 . 0 3 9} \\
(0.024)\end{array}$ & $\begin{array}{c}\mathbf{0 . 0 2 7} \\
(0.019)\end{array}$ & $\begin{array}{c}\mathbf{0 . 0 3 0} * * \\
(0.014)\end{array}$ & $\begin{array}{c}\mathbf{0 . 0 2 7} * \\
(0.014)\end{array}$ \\
\hline$R^{2}$ & 0.36 & 0.35 & 0.31 & 0.35 & 0.32 & 0.29 \\
\hline$N$ & 37 & 45 & 57 & 71 & 86 & 105 \\
\hline $\begin{array}{l}\text { Imputed effect of a mark of } \\
40 \text { in resit } \\
\text { Imputed effect of a mark of } \\
70 \text { in resit }\end{array}$ & $\begin{array}{c}\mathbf{0 . 9 3 8} \\
(0.976) \\
\mathbf{0 . 8 2 8} \\
(0.570) \\
\end{array}$ & $\begin{array}{c}\mathbf{0 . 1 5 8} \\
(0.969) \\
\mathbf{0 . 3 6 2} \\
(0.505) \\
\end{array}$ & $\begin{array}{c}\mathbf{- 0 . 6 5 4} \\
(0.834) \\
\mathbf{0 . 5 0 3} \\
(0.499) \\
\end{array}$ & $\begin{array}{l}\mathbf{- 0 . 1 6 1} \\
(0.674) \\
\mathbf{0 . 6 6 2} * \\
(0.393) \\
\end{array}$ & $\begin{array}{l}\mathbf{- 0 . 2 1 1} \\
(0.535) \\
\mathbf{0 . 6 8 0 *} \\
(0.342) \\
\end{array}$ & $\begin{array}{r}\mathbf{- 0 . 1 0 9} \\
(0.486) \\
\mathbf{0 . 7 0 5} * * \\
(0.332) \\
\end{array}$ \\
\hline \multicolumn{7}{|l|}{$\underline{\text { Macroeconomics }}$} \\
\hline Resit & $\begin{array}{c}\mathbf{- 0 . 4 0 0} \\
(1.579)\end{array}$ & $\begin{array}{c}\mathbf{- 1 . 9 7 0} \\
(1.941)\end{array}$ & $\begin{array}{c}\mathbf{- 1 . 2 2 6} \\
(1.290)\end{array}$ & $\begin{array}{c}\mathbf{- 1 . 7 5 7} \\
(1.174)\end{array}$ & $\begin{array}{c}-\mathbf{1 . 9 1 0}^{* *} \\
(0.938)\end{array}$ & $\begin{array}{c}\mathbf{- 1 . 5 8 6} * \\
(0.841)\end{array}$ \\
\hline Resit mark & $\begin{array}{c}\mathbf{0 . 0 1 4} \\
(0.025)\end{array}$ & $\begin{array}{c}\mathbf{0 . 0 3 0} \\
(0.030)\end{array}$ & $\begin{array}{c}\mathbf{0 . 0 2 2} \\
(0.020)\end{array}$ & $\begin{array}{c}\mathbf{0 . 0 3 3}^{*} \\
(0.017)\end{array}$ & $\begin{array}{c}\mathbf{0 . 0 3 6}^{* *} \\
(0.014)\end{array}$ & $\begin{array}{c}\mathbf{0 . 0 3 0}^{* * *} \\
(0.013)\end{array}$ \\
\hline$R^{2}$ & 0.34 & 0.31 & 0.28 & 0.30 & 0.28 & 0.28 \\
\hline$N$ & 37 & 45 & 57 & 71 & 86 & 105 \\
\hline $\begin{array}{l}\text { Imputed effect of a mark of } \\
40 \text { in resit } \\
\text { Imputed effect of a mark of } \\
70 \text { in resit }\end{array}$ & $\begin{array}{c}\mathbf{0 . 1 6 2} \\
(0.841) \\
\mathbf{0 . 5 8 4} \\
(0.805) \\
\end{array}$ & $\begin{array}{c}\mathbf{- 0 . 7 8 5} \\
(0.869) \\
\mathbf{0 . 1 0 4} \\
(0.635) \\
\end{array}$ & $\begin{array}{c}\mathbf{- 0 . 3 4 3} \\
(0.640) \\
\mathbf{0 . 3 1 9} \\
(0.528) \\
\end{array}$ & $\begin{array}{c}\mathbf{- 0 . 4 4 2} \\
(0.572) \\
\mathbf{0 . 5 4 5} \\
(0.427) \\
\end{array}$ & $\begin{array}{c}\mathbf{- 0 . 4 8 5} \\
(0.464) \\
\mathbf{0 . 5 8 3} \\
(0.392) \\
\end{array}$ & $\begin{array}{c}\mathbf{- 0 . 4 0 4} \\
(0.403) \\
\mathbf{0 . 4 8 2} \\
(0.357) \\
\end{array}$ \\
\hline \multicolumn{7}{|l|}{$\underline{\text { Econometrics }}$} \\
\hline Resit & $\begin{array}{c}\mathbf{- 0 . 5 1 8} \\
(1.782)\end{array}$ & $\begin{array}{c}\mathbf{- 0 . 0 5 0} \\
(1.722)\end{array}$ & $\begin{array}{l}\mathbf{- 1 . 2 1 5} \\
(1.583)\end{array}$ & $\begin{array}{l}\mathbf{- 1 . 4 6 9} \\
(1.987)\end{array}$ & $\begin{array}{c}\mathbf{- 2 . 0 5 3} \\
(1.498)\end{array}$ & $\begin{array}{c}\mathbf{- 1 . 5 8 8} \\
(1.460)\end{array}$ \\
\hline Resit mark & $\begin{array}{c}\mathbf{0 . 0 1 1} \\
(0.030)\end{array}$ & $\begin{array}{c}\mathbf{- 0 . 0 0 2} \\
(0.028)\end{array}$ & $\begin{array}{c}\mathbf{0 . 0 2 0} \\
(0.023)\end{array}$ & $\begin{array}{c}\mathbf{0 . 0 2 6} \\
(0.029)\end{array}$ & $\begin{array}{c}\mathbf{0 . 0 3 1} \\
(0.021)\end{array}$ & $\begin{array}{c}\mathbf{0 . 0 2 7} \\
(0.020)\end{array}$ \\
\hline$R^{2}$ & 0.61 & 0.47 & 0.69 & 0.45 & 0.37 & 0.31 \\
\hline$N$ & 24 & 27 & 35 & 44 & 53 & 66 \\
\hline $\begin{array}{l}\text { Imputed effect of a mark of } \\
40 \text { in resit } \\
\text { Imputed effect of a mark of } \\
70 \text { in resit }\end{array}$ & $\begin{array}{c}\mathbf{- 0 . 0 8 7} \\
(0.858) \\
\mathbf{0 . 2 3 7} \\
(0.906) \\
\end{array}$ & $\begin{array}{l}\mathbf{- 0 . 1 4 6} \\
(0.802) \\
\mathbf{- 0 . 2 1 7} \\
(0.770) \\
\end{array}$ & $\begin{array}{c}\mathbf{- 0 . 4 1 6} \\
(0.765) \\
\mathbf{0 . 1 8 4} \\
(0.500) \\
\end{array}$ & $\begin{array}{c}\mathbf{- 0 . 4 3 3} \\
(0.896) \\
\mathbf{0 . 3 4 3} \\
(0.437) \\
\end{array}$ & $\begin{array}{c}\mathbf{- 0 . 8 0 3} \\
(0.715) \\
\mathbf{0 . 1 3 5} \\
(0.353) \\
\end{array}$ & $\begin{array}{c}\mathbf{- 0 . 5 0 4} \\
(0.692) \\
\mathbf{0 . 3 0 8} \\
(0.341) \\
\end{array}$ \\
\hline $\begin{array}{l}\text { Note: Dependent variable is } \\
\text { Dependent variables are stan } \\
\text { are similarly standardised. I } \\
\text { indicates that the student hac } \\
\text { The resit mark is the mark ga } \\
\text { in June examinations in mi } \\
\text { indicates significant at } 1 \% \text { si } \\
\text { at } 10 \% \text { significance level. Ro }\end{array}$ & $\begin{array}{l}\text { utcome at } \\
\text { sed to mea } \\
\text { nies are inc } \\
\text { sit examin } \\
\text { in the resit } \\
\text { onomics, n } \\
\text { ance level, } \\
\text { standard er }\end{array}$ & $\begin{array}{l}\text { end of the } \\
\text { ro, standar } \\
\text { ed for yea } \\
\text { in first y } \\
\text { mination; } t \\
\text { oeconomic } \\
\text { indicates s }\end{array}$ & $\begin{array}{l}\text { nd year in } \\
\text { viation on } \\
\text { student } \\
\text { tatistics } \mathrm{y} \\
\text { ass mark i } \\
\text { athematic }\end{array}$ & $\begin{array}{l}\text { cro- macr } \\
\text { y examina } \\
\text { heir secon } \\
\text { economet } \\
\text {. Control } \\
\text { d, statisti }\end{array}$ & $\begin{array}{l}\text { omics or ec } \\
\text { year. Prior } \\
\text { ar examina } \\
\text { but in no o } \\
\text { included fo } \\
\text { ith econom }\end{array}$ & $\begin{array}{l}\text { ometrics. } \\
\text { tainments } \\
\text { as. Resit } \\
\text { r subject. } \\
\text { ttainment } \\
\text { ics. } * * * \\
\text { ignificant }\end{array}$ \\
\hline
\end{tabular}


Table 8. Robustness test - only including the years $2010-2012$.

\begin{tabular}{|c|c|c|c|c|c|c|}
\hline & I & II & III & IV & $\mathrm{V}$ & VI \\
\hline \multicolumn{7}{|l|}{$\underline{\text { Microeconomics }}$} \\
\hline Resit & $\begin{array}{c}\mathbf{1 . 2 1 7} \\
(2.276)\end{array}$ & $\begin{array}{c}\mathbf{0 . 1 8 0} \\
(2.277)\end{array}$ & $\begin{array}{c}\mathbf{- 1 . 6 8 2} \\
(2.054)\end{array}$ & $\begin{array}{c}\mathbf{- 0 . 9 1 9} \\
(1.604)\end{array}$ & $\begin{array}{c}\mathbf{- 1 . 1 3 6} \\
(1.220)\end{array}$ & $\begin{array}{c}\mathbf{- 0 . 9 7 9} \\
(1.227)\end{array}$ \\
\hline Resit mark & $\begin{array}{c}\mathbf{0 . 0 0 3} \\
(0.036)\end{array}$ & $\begin{array}{c}\mathbf{0 . 0 0 5} \\
(0.032)\end{array}$ & $\begin{array}{c}\mathbf{0 . 0 3 4} \\
(0.027)\end{array}$ & $\begin{array}{c}\mathbf{0 . 0 2 4} \\
(0.023)\end{array}$ & $\begin{array}{c}\mathbf{0 . 0 2 9} \\
(0.017)\end{array}$ & $\begin{array}{c}\mathbf{0 . 0 2 5} \\
(0.018)\end{array}$ \\
\hline$R^{2}$ & 0.34 & 0.29 & 0.24 & 0.30 & 0.31 & 0.28 \\
\hline$N$ & 31 & 38 & 44 & 55 & 64 & 75 \\
\hline $\begin{array}{l}\text { Imputed effect of a mark of } \\
40 \text { in resit } \\
\text { Imputed effect of a mark of } \\
70 \text { in resit }\end{array}$ & $\begin{array}{c}\mathbf{1 . 3 3 9} \\
(0.985) \\
\mathbf{1 . 4 3 1 *} \\
(0.727) \\
\end{array}$ & $\begin{array}{c}\mathbf{0 . 3 8 5} \\
(1.082) \\
\mathbf{0 . 5 3 9} \\
(0.564) \\
\end{array}$ & $\begin{array}{c}\mathbf{- 0 . 3 1 1} \\
(1.054) \\
\mathbf{0 . 7 1 8} \\
(0.568) \\
\end{array}$ & $\begin{array}{c}\mathbf{0 . 0 3 9} \\
(0.775) \\
\mathbf{0 . 7 5 8} \\
(0.453) \\
\end{array}$ & $\begin{array}{c}\mathbf{0 . 0 2 3} \\
(0.616) \\
\mathbf{0 . 8 9 3} * * \\
(0.430) \\
\end{array}$ & $\begin{array}{c}\mathbf{0 . 0 2 8} \\
(0.608) \\
\mathbf{0 . 7 8 4} * \\
(0.448) \\
\end{array}$ \\
\hline \multicolumn{7}{|l|}{ Macroeconomics } \\
\hline Resit & $\begin{array}{c}\mathbf{1 . 1 2 1} \\
(1.408)\end{array}$ & $\begin{array}{c}\mathbf{- 0 . 9 8 4} \\
(2.041)\end{array}$ & $\begin{array}{c}\mathbf{- 0 . 7 6 7} \\
(1.513)\end{array}$ & $\begin{array}{c}\mathbf{- 1 . 0 3 1} \\
(1.213)\end{array}$ & $\begin{array}{c}\mathbf{- 1 . 6 3 1 *} \\
(0.944)\end{array}$ & $\begin{array}{c}\mathbf{- 1 . 4 6 0} \\
(0.913)\end{array}$ \\
\hline Resit mark & $\begin{array}{c}\mathbf{- 0 . 0 0 7} \\
(0.025)\end{array}$ & $\begin{array}{c}\mathbf{0 . 0 1 6} \\
(0.031)\end{array}$ & $\begin{array}{c}\mathbf{0 . 0 1 6} \\
(0.022)\end{array}$ & $\begin{array}{c}\mathbf{0 . 0 2 0} \\
(0.017)\end{array}$ & $\begin{array}{c}\mathbf{0 . 0 2 9} * * \\
(0.013)\end{array}$ & $\begin{array}{l}\mathbf{0 . 0 2 7} * \\
(0.014)\end{array}$ \\
\hline$R^{2}$ & 0.37 & 0.33 & 0.26 & 0.26 & 0.27 & 0.29 \\
\hline$N$ & 31 & 38 & 44 & 55 & 64 & 75 \\
\hline $\begin{array}{l}\text { Imputed effect of a mark of } \\
40 \text { in resit } \\
\text { Imputed effect of a mark of } \\
70 \text { in resit }\end{array}$ & $\begin{array}{c}\mathbf{0 . 8 2 8} \\
(0.788) \\
\mathbf{0 . 6 0 8} \\
(0.940) \\
\end{array}$ & $\begin{array}{c}\mathbf{- 0 . 3 4 5} \\
(0.918) \\
\mathbf{0 . 1 3 4} \\
(0.637) \\
\end{array}$ & $\begin{array}{c}\mathbf{- 0 . 1 4 7} \\
(0.752) \\
\mathbf{0 . 3 1 8} \\
(0.534) \\
\end{array}$ & $\begin{array}{c}\mathbf{- 0 . 2 2 0} \\
(0.626) \\
\mathbf{0 . 3 8 9} \\
(0.423) \\
\end{array}$ & $\begin{array}{c}\mathbf{- 0 . 4 7 3} \\
(0.512) \\
\mathbf{0 . 3 9 5} \\
(0.404) \\
\end{array}$ & $\begin{array}{c}\mathbf{- 0 . 3 8 1} \\
(0.474) \\
\mathbf{0 . 4 2 7} \\
(0.392) \\
\end{array}$ \\
\hline $\begin{array}{l}\text { Note: Dependent variable is } \\
\text { Dependent variables are stand } \\
\text { are similarly standardised. D } \\
\text { indicates that the student had } \\
\text { The resit mark is the mark gai } \\
\text { in June examinations in micr } \\
\text { indicates significant at } 1 \% \text { sig } \\
\text { at } 10 \% \text { significance level. Ro }\end{array}$ & $\begin{array}{l}\text { edcome at } t \\
\text { ed to mear } \\
\text { ies are inc } \\
\text { it examin } \\
\mathrm{n} \text { the resit } \\
\text { nomics, m } \\
\text { ance level, } \\
\text { tandard er }\end{array}$ & $\begin{array}{l}\text { nd of the s } \\
o \text {, standar } \\
\text { d for year } \\
\text { in first ye } \\
\text { nination; } t \\
\text { economics } \\
\text { ndicates si } \\
\text { in parenthe }\end{array}$ & $\begin{array}{l}\text { nd year in } \\
\text { viation on } \\
\text { it student } \\
\text { tatistics w } \\
\text { ass mark i } \\
\text { athematics } \\
\text { icant at 5\% }\end{array}$ & $\begin{array}{l}\text { o- macro- } \\
\text { examinat } \\
\text { heir secon } \\
\text { econometri } \\
\text { Controls } \\
\text { statistics } \\
\text { nificance }\end{array}$ & $\begin{array}{l}\text { omics or } \\
\text { ear. Prio } \\
\text { or examin } \\
\text { ut in no } \\
\text { ecluded } \mathrm{f} \\
\text { econom }\end{array}$ & $\begin{array}{l}\text { ometrics. } \\
\text { ainments } \\
\text { is. Resit } \\
\text { subject. } \\
\text { tainment } \\
\text { s. } \quad * * * \\
\text { gnificant }\end{array}$ \\
\hline
\end{tabular}


Table 9. Test of validity of regression discontinuity design

\begin{tabular}{|c|c|c|c|c|c|c|}
\hline & I & II & III & IV & V & VI \\
\hline \multicolumn{7}{|l|}{$\underline{\text { Microeconomics }}$} \\
\hline $\begin{array}{l}\text { Difference in fitted value } \\
\text { between resit and non-resit } \\
\text { group }\end{array}$ & $\begin{array}{c}0.354 \\
(0.381)\end{array}$ & $\begin{array}{c}-0.074 \\
(0.174)\end{array}$ & $\begin{array}{c}0.041 \\
(0.115)\end{array}$ & $\begin{array}{c}-0.046 \\
(0.118)\end{array}$ & $\begin{array}{c}0.038 \\
(0.105)\end{array}$ & $\begin{array}{c}0.009 \\
(0.096)\end{array}$ \\
\hline \multicolumn{7}{|l|}{$\underline{\text { Macroeconomics }}$} \\
\hline $\begin{array}{l}\text { Difference in fitted value } \\
\text { between resit and non-resit } \\
\text { group }\end{array}$ & $\begin{array}{c}0.311 \\
(0.361)\end{array}$ & $\begin{array}{c}-0.004 \\
(0.108)\end{array}$ & $\begin{array}{c}-0.035 \\
(0.112)\end{array}$ & $\begin{array}{c}-0.112 \\
(0.088)\end{array}$ & $\begin{array}{c}-0.039 \\
(0.075)\end{array}$ & $\begin{array}{c}-0.042 \\
(0.074)\end{array}$ \\
\hline \multicolumn{7}{|l|}{$\underline{\text { Econometrics }}$} \\
\hline $\begin{array}{l}\text { Difference in fitted value } \\
\text { between resit and non-resit } \\
\text { group }\end{array}$ & $\begin{array}{c}0.126 \\
(0.250)\end{array}$ & $\begin{array}{c}0.049 \\
(0.311)\end{array}$ & $\begin{array}{c}0.084 \\
(0.196)\end{array}$ & $\begin{array}{c}-0.153 \\
(0.182)\end{array}$ & $\begin{array}{c}-0.089 \\
(0.164)\end{array}$ & $\begin{array}{c}-0.097 \\
(0.119)\end{array}$ \\
\hline
\end{tabular}

\footnotetext{
Note: The difference in mean is estimated using an OLS regression of fitted value based against a dummy variable for whether the student experiences a resit or not. Robust standard errors are reported in parentheses. *** indicates significant at $1 \%$ significance level, ** indicates significant at 5\% significance level, * indicates significant at $10 \%$ significance level. Robust standard errors in parentheses
} 